\title{
PENGARUH JUMLAH DAN UMUR BIBIT TERHADAP PERTUMBUHAN DAN HASIL PADI PADA LAHAN SAWAH TADAH HUJAN
}

\author{
Sony Setiawan ${ }^{1}, \operatorname{Radian}^{2}$, Tatang Abdurrahman ${ }^{2}$ \\ ${ }^{1}$ Mahasiswa Magister Agroteknologi Fakultas Pertanian \\ ${ }^{2}$ Dosen Fakultas Pertanian Universitas Tanjungpura Pontianak. \\ E-Mail: radian@faperta.untan.ac.id
}

\begin{abstract}
ABSTRAK
Pengaruh Jumlah Dan Umur Bibit Terhadap Pertumbuhan Dan Hasil Padi Pada Lahan Sawah Tadah Hujan. Lahan sawah tadah hujan sebagai lahan yang paling banyak dimanfaatkan untuk pertanaman padi adalah juga merupakan ekosistem yang beresiko tinggi karena sangat mungkin terjadi kekeringan, kebanjiran atau pasang surutnya air laut yang menyebabkan produksi padi pada lahan sawah tadah hujan cenderung rendah. Jumlah bibit perlubang tanam dan umur pindah tanam merupakan beberapa faktor penting yang menentukan keberhasilan dalam kegiatan produksi tanaman padi.Penelitian ini bertujuan untuk mengetahui apakah teradi interaksi antara jumlah bibit dan umur bibit dan untuk mengetahui jumlah bibit dan umur bibit terbaik bagi pertumbuhan dan hasil tanaman padi pada lahan sawah tadah hujan. Penelitian berlokasi di Balai Benih Hortikultura Dinas Pertanian, Perikanan dan Peternakan Kabupaten Sanggau dengan lahan sawah tadah hujan tanah aluvial.

Metode yang digunakan adalah Rancangan Acak Kelompok, disusun secara faktorial dan terdiri dari dua faktor yaitu jumlah bibit pertitik tanam (J) terdiri dari 5 taraf 5 bibit pertitik tanam (j1), 10 bibit pertitik tanam (j2), 15 bibit pertitik tanam (j3), 20 bibit pertitik tanam (j4) dan 25 bibit pertitik tanam (j5). Dan umur bibit (U) terdiri dari 14 HSS (u1), 21 HSS (u2), 28 HSS (u3) dan 35 HSS (u4). Variabel pengamatan meliputi tinggi tanaman, jumlah anakan maksimum, jumlah anakan produktif, berat gabah kering panen, berat 1.000 butir gabah, berat gabah kering giling pertanaman, berat gabah kering giling.

Hasil penelitian menunjukkan bahwa tidak terdapat interaksi antara perlakuan jumlah bibit dan umur bibit terhadap pertumbuhan dan hasil padi pada lahan sawah tadah hujan. Perlakuan jumlah bibit 5 pertitik tanam dan perlakuan umur bibit 21 HSS merupakan perlakuan terbaik dalam meningkatkan pertumbuhan hasil tanaman padi pada lahan sawah tadah hujan.
\end{abstract}

Kata kunci : Jumlah Bibit, Lahan Sawah Tadah Hujan, Padi, Umur Bibit.

\begin{abstract}
Effect of Seedling Number and Age on Growth and Yield of Rice on Rain-fed Rice Fields. Rain-fed Rice Fields as the most used land for rice cultivation is also a high-risk cosystem because it is very likely to occur drought, flooding or tidal water which causes rice production in Rain-fed Rice Fields tends to be low. The number of seedlings per planting and the age of transplanting are some important factors that determine success in rice production activities. This study aims to know the connection between the number of seed and age of seed and to determine the bes number of seed and age of seed for growth and the results of Rice plants in the rain-fed fields. The research is located at the Horticultural Seed Institute of Agriculture, Fisheries and Animal Husbandry, Sanggau District with alluvial rain-fed rice fields.

The method used was Randomized Block Design, arranged factorially and consisted of two factors: the number of planting point seeds $(\mathrm{J})$ consisting of 5 levels of 5 planting point seeds $(j 1), 10$ planting point seeds (j2), 15 planting point seeds (j3) ), 20 planting dotted seeds (j4) and 25 planting dotted seeds (j5). And seedling age (U) consists of 14 HSS (u1), 21 HSS (u2), 28 HSS (u3) and 35 HSS (u4). Observation variables included plant height, maximum number of tillers, number of productive tillers, weight of harvested unhusked rice, weight of 1,000 grains, weight of unhulled rice unhusked, dry weight of unhusked rice.

The results showed that there was no interaction between the treatment of the number of seedlings and the age of the seeds on the growth and yield of rice in rain-fed rice field. The number of 5 planting point seeds
\end{abstract}


and the age of 21 HSS seedlings were the best treatment in increasing the growth of rice yields in rain-fed rice fields.

Key words : Age on Growth, Rain-fed Rice Fields, Rice, Seedling Number.

\section{PENDAHULUAN}

Padi merupakan tanaman pangan terpenting kedua di dunia yang digunakan sebagai sumber bahan pangan setelah gandum dan masih menjadi bahan pangan utama bagi sebagian besar masyarakat di Indonesia. Di Kabupaten Sanggau lahan yang paling banyak dimanfaatkan untuk pertanaman padi adalah lahan sawah tadah hujan dengan produktivitas padi sawah pada tahun 2014 hanya sekitar 3,24 ton perhektar yang berarti masih dibawah angka produktivitas padi Provinsi Kalimantan Barat dan Nasional (Badan Pusat Provinsi Kalimantan Barat, 2014).Sawah tadah hujan adalah sawah yang sumber airnya tergantung dari curah hujan tanpa adanya bangunan-bangunan irigasi permanen, umumnya terdapat pada wilayah yang posisinya lebih tinggi dari sawah irigasi atau sawah lainnya sehingga tidak memungkinkan terjangkau oleh pengairan.

Jumlah bibit per lubang tanam merupakan salah satu faktor penting yang menentukan keberhasilan dalam kegiatan produksi tanaman padi. Jumlah bibit per lubang tanam sangat terkait dengan persaingan tanaman dalam satu rumpun maupun dengan rumpun lainnya terhadap cahaya, ruang dan pemanfaatan unsur hara oleh tanaman sehingga dapat mempengaruhi pertumbuhan dan hasil padi. Faktor penting lain pada budidaya padi adalah umur pindah tanam. Umur pindah tanam merupakan salah satu faktor penting yang menentukan baik atau tidaknya hasil pertanaman padi.

Upaya peningkatan produksi tanaman padi dihadapakan pada sejumlah kendala teknis di lapangan. Salah satu faktor yang menunjang keberhasilan dalam pengembangan padi adalah pengaturan jumlah bibit. Jumlah bibit pada satu lubang tanam perlu dipertimbangkan batas efektifitasnya mengingat jika kerapatan tanaman terlalu tinggi akan mengakibatkan tingginya tingkat kompetisi makanan dan sumber cahaya. Jika terjadi kompetisi yang tinggi antara makanan dan cahaya maka dikhawatirkan proses fotosintesis tidak berjalan sebagaimana yang diharapkan.

Selain itu, umur pindah tanam bibit juga perlu diperhatikan dimana hal yang menjadi pertimbangan dalam menentukan umur pindah tanam bibit adalah jika terlalu muda umur bibit pada saat dipindahkan dikhawatirkan daya adaptasi dari bibit tanaman masih rendah. Namun disisi lain umur pindah bibit tanaman yang muda dapat memberikan kesempatan kepada tanaman untuk menghasilkan anakan yang lebih banyak, sedangkan jika umur pindah tanam bibit terlalu lama maka yang perlu menjadi perhatian kita adalah daerah perakaran yang dikhawatirkan akan banyak terjadi kerusakan dan kesempatan untuk menghasilkan anakan lagi semakin berkurang.

Adapun tujuan dari penelitian ini adalah untuk mengetahui interaksi antara jumlah bibit dan umur bibit terhadap pertumbuhan dan hasil tanaman padi pada lahan sawah tadah hujan serta mendapatkan jumlah bibit dan umur bibit yang terbaik bagi pertumbuhan dan hasil tanaman padi pada lahan sawah tadah hujan.

\section{METODA PENELITIAN}

\subsection{Tempat dan Waktu}

Penelitian ini dilaksanakan pada lahan sawah tadah hujan yang berlokasi di Balai Benih Hortikultura 
Dinas Pertanian, Perikanan dan Peternakan Kabupaten Sanggau Kecamatan Kapuas Kabupaten Sanggau. Tanah pada lokasi penelitian adalah tanah aluvial. Analisis tanah dilaksanakan di Laboratorium Tanah Universitas Tanjungpura Pontianak. Penelitian dilaksanakan selama 4 bulan yang dimulai dari 17 September 2016 sampai 7 Februari 2017.

\subsection{Bahan dan Alat}

Alat yang digunakan di dalam penelitian ini diantaranya adalah alat tulis, hand traktor, power threser, thermometer, meteran, cangkul, parang, bilah pelarik dan tali untuk meluruskan jarak tanam sesuai dengan keperluan, timbangan analitik.Bahan yang digunakan di dalam penelitian ini adalah benih padi varietas Cilosari. Pupuk yang diberikan yaitu urea, SP-36, dan $\mathrm{KCl}$ serta pupuk kotoran ayam. Pestisida, insektisida pengendali hama penyakit dan fungisida yang diperlukan sesuai dengan jenis serangan yang terjadi pada pertanaman.

\subsection{Rancangan Percobaan}

Rancangan percobaan yang digunakan di dalam penelitian ini adalah Rancangan Acak Kelompok, disusun secara faktorial yang terdiri dari dua faktor. Faktor pertama adalah jumlah bibit perlubang tanam yang terdiri dari 5 taraf perlakuan. Faktor kedua adalah umur bibit yang terdiri dari 4 taraf perlakuan. Jumlah seluruh kombinasi perlakuan adalah 20 kombinasi dengan jumlah ulangan 3 kali sehingga akan ada 60 satuan perlakuan. Adapun kombinasi perlakuannya sebagai berikut: Faktor pertama adalah jumlah bibit per titik tanam $(\mathrm{J})$, terdiridari: $\mathrm{j}_{1}=5$ bibit, $\mathrm{j}_{2}=$ 10 bibit, $\mathrm{j}_{3}=15$ bibit, $\mathrm{j}_{4}=20$ bibit, $\mathrm{j}_{5}$ $=25$ bibit. Faktor kedua adalah umur bibit (U), terdiri dari: $\mathrm{u}_{1}=$ umur bibit $14 \mathrm{HSS}, \mathrm{u}_{2}=$ umur bibit $21 \mathrm{HSS}, \mathrm{u}_{3}=$ umur bibit $28 \mathrm{HSS}, \mathrm{u}_{4}=$ bibit umur 35 HSS. Setiap satuan perlakuan ditempatkan di atas petakan sawah berukuran $1 \mathrm{~m}$ x $0,75 \mathrm{~m}$, dengan jarak tanam $25 \mathrm{~cm} \times 25 \mathrm{~cm}$. Jarak antar petak sebesar $40 \mathrm{~cm}$.

\subsection{Tahapan Pelaksanaan Penelitian}

Adapun tahapan pelaksaan penelitian mulai dari Persiapan Lahan, Persiapan bibit, Pemberian Kapur, Penanaman, Pemeliharaan tanaman, Penyiangan dan Panen. Setelah dipanen, tanaman padi yang dijadikan sampel dijemur selama 2 hari dan disimpan pada amplop yang dibuat dari koran. Variabel pengamatan dilakukan terhadap pertumbuhan dan hasil tanaman yaitu Tinggi tanaman $(\mathrm{cm})$, Jumlah anakan maksimum, Jumlah anakan produktif, Berat gabah kering panen $(\mathrm{g})$, Berat 1.000 butir gabah (g), Berat gabah kering giling pertanaman (g) dan Berat gabah kering giling per petak (g). Selain pengamatan pada variabel tanaman, dilakukan pula pengamatan terhadap faktor lingkungan, yaitu Suhu, Kelembaban (RH), Curah Hujan.Data yang diperoleh dari hasil pengamatan selanjutnya disusun menurut perlakuannya dan kemudian dilakukan analisis keragaman. Jika hasil analisis keragaman menunjukkan bahwa perlakuan berpengaruh nyata maupun sangat nyata, maka dilanjutkan dengan uji beda nyata jujur (BNJ) pada tingkat kepercayaan 5\% untuk menentukan perbedaan antar perlakuan mana yang memberikan hasil terbaik.

\section{HASIL PENELITIAN DAN PEMBAHASAN}

\subsection{Tinggi Tanaman $(\mathrm{cm})$}


Hasil analisis keragaman pengaruh tanaman dapat dilihat pada Tabel 1 berikut jumlah dan umur bibit terhadap tinggi ini.

Tabel 1. Analisis Keragaman Pengaruh Jumlah Bibit dan Umur Bibit Terhadap Tinggi Tanaman

\begin{tabular}{|c|c|c|c|c|c|c|c|}
\hline \multirow{2}{*}{$\begin{array}{l}\text { Sumber } \\
\text { Keragaman }\end{array}$} & \multirow{2}{*}{$\begin{array}{c}\text { Derajat } \\
\text { Bebas }\end{array}$} & \multicolumn{5}{|c|}{ F hitung } & \multirow{2}{*}{$\begin{array}{l}\text { F tabel } \\
5 \%\end{array}$} \\
\hline & & $1 \mathrm{MST}$ & $2 \mathrm{MST}$ & $3 \mathrm{MST}$ & $4 \mathrm{MST}$ & $5 \mathrm{MST}$ & \\
\hline Kelompok & 2 & $0,83^{\text {tn }}$ & $0,77^{\mathrm{tn}}$ & $0,15^{\mathrm{tn}}$ & $2,29^{\mathrm{tn}}$ & $3,19^{\text {tn }}$ & 3,24 \\
\hline Jumlah Bibit & 4 & $1,13^{\mathrm{tn}}$ & $3,82^{*}$ & $0,42^{\text {tn }}$ & $2,98^{*}$ & $16,52^{*}$ & 2,62 \\
\hline Umur Bibit & 3 & $1,49^{\operatorname{tn}}$ & $5,75^{*}$ & $4,71^{*}$ & $4,71^{*}$ & $0,88^{\operatorname{tn}}$ & 2,85 \\
\hline Interaksi & 12 & $1,71^{\mathrm{tn}}$ & $1,05^{\mathrm{tn}}$ & $0,55^{\mathrm{tn}}$ & $1,55^{\mathrm{tn}}$ & $1,04^{\mathrm{tn}}$ & 2,02 \\
\hline Galat & 38 & & & & & & \\
\hline Total & 59 & & & & & & \\
\hline KK (\%) & & 8,97 & 7,20 & 7,24 & 5,74 & 6,02 & \\
\hline
\end{tabular}

Keterangan: $t n=$ berpengaruh tidak nyata, *=Berpengaruh nyata,MST=Minggu Setelah Tanam

Berdasarkan hasil analisis keragaman pada Tabel 1, jumlah bibit, umur bibit dan interaksi perlakuan menunjukkan pengaruh yang tidak nyata terhadap tinggi tanaman umur 1 MST. Pada umur 2 MST, jumlah bibit berpengaruh nyata terhadap tinggi tanaman, sedangkan umur bibit dan interaksinya berpengaruh tidak nyata. Pada umur 3 MST, umur bibit berpengaruh nyata terhadap tinggi tanaman, sedangkan jumlah bibit dan interaksinya berpengaruh tidak nyata, Pada umur 4 MST, jumlah bibit dan umur bibit berpengaruh nyata terhadap tinggi tanaman, sedangkan interaksinya berpengaruh tidak nyata. Pada umur 5 MST, jumlah bibit berpengaruh nyata terhadap tinggi tanaman, sedangkan umur bibit dan interaksinya berpengaruh tidak nyata.

Tabel 2. Uji BNJ Perlakuan Jumlah Bibit Terhadap Tinggi Tanaman

\begin{tabular}{lccc}
\hline \multirow{2}{*}{ Jumlah Bibit } & \multicolumn{3}{c}{ Tinggi Tanaman $(\mathrm{cm})$} \\
\cline { 2 - 4 } & 2 MST & 4 MST & 5 MST \\
\hline 5 & $23,17 \mathrm{~b}$ & $42,67 \mathrm{ab}$ & $52,83 \mathrm{~b}$ \\
10 & $23,92 \mathrm{ab}$ & $44,00 \mathrm{ab}$ & $55,17 \mathrm{~b}$ \\
15 & $24,75 \mathrm{ab}$ & $42,33 \mathrm{~b}$ & $54,75 \mathrm{~b}$ \\
20 & $24,58 \mathrm{ab}$ & $42,75 \mathrm{ab}$ & $55,67 \mathrm{~b}$ \\
25 & $25,83 \mathrm{a}$ & $45,33 \mathrm{a}$ & $63,16 \mathrm{a}$ \\
\hline BNJ 5\% & 2,06 & 2,91 & 3,96 \\
\hline
\end{tabular}

Keterangan: Nilai yang diikuti dengan huruf yang berbeda menunjukkan perlakuan berbeda nyata pada taraf uji BNJ 5\% 
Uji BNJ pada Tabel 2, menunjukkan bahwa tinggi tanaman pada umur 2 MST pada perlakuan jumlah bibit 5 pertitik tanam berbeda tidak nyata dengan perlakuan jumlah bibit 10, 15, dan 20 pertitik tanam, namun berbeda nyata dengan perlakuan jumlah bibit 25 pertitik tanam. Selanjutnya pada perlakuan umur bibit 4 MST terlihat bahwa perlakuan jumlah bibit 15 pertitik tanam berbeda tidak nyata dengan jumlah bibit 5 , 10, 20 pertitik tanam, namun berbeda nyata pada perlakuan jumlah bibit 25 pertitik tanam. Pada umur 5 MST, jumlah bibit 5 pertitik tanam menunjukkan hasil yang berbeda tidak nyata pada perlakuan jumlah bibit 10, 15 dan 20 pertitik tanam, tetapi berbeda nyata pada perlakuan jumlah bibit 25 pertitik tanam. Hasil tertinggi dari jumlah bibit 2 MST, 3 MST, 4 MST dan 5 MST cenderung ditunjukkan pada perlakuan jumlah bibit 15 pertitik tanam. Selain jumlah bibit yang berpengaruh terhadap hasil tinggi tanaman, umur bibit juga mempengaruhi tinggi tanaman. Hasil uji BNJ pengaruh umur bibit terhadap tinggi tanaman disajikan pada Tabel 3 dibawah ini.

Tabel 3. Uji BNJ Perlakuan Umur Bibit Terhadap Tinggi Tanaman

\begin{tabular}{llll}
\hline \multirow{2}{*}{ Umur Bibit (HSS) } & \multicolumn{3}{l}{ Variabel Pengamatan $(\mathrm{cm})$} \\
\cline { 2 - 4 } & $2 \mathrm{MST}$ & $3 \mathrm{MST}$ & $4 \mathrm{MST}$ \\
\hline 14 & $24,13 \mathrm{ab}$ & $31,40 \mathrm{ab}$ & $43,00 \mathrm{ab}$ \\
21 & $23,07 \mathrm{~b}$ & $30,40 \mathrm{~b}$ & $41,67 \mathrm{~b}$ \\
28 & $25,07 \mathrm{ab}$ & $33,00 \mathrm{ab}$ & $44,87 \mathrm{a}$ \\
35 & $25,53 \mathrm{a}$ & $33,07 \mathrm{a}$ & $44,13 \mathrm{ab}$ \\
\hline BNJ 5\% & 1,73 & 2,27 & 2,45
\end{tabular}

Keterangan: Angka yang diikuti dengan huruf yang berbeda menunjukkan perlakuan berbeda nyata pada taraf uji BNJ 5\%.

Berdasarkan Tabel 3 bahwa rerata tinggi tanaman umur 2 dan 3 MST pada perlakuan 35 HSS berbeda nyata dengan umur bibit 21 HSS, namun berbeda tidak nyata pada umur bibit 14 dan 28 HSS. Selanjutnya pada minggu ke-4 dapat dilihat bahwa pada perlakuan 28 HSS berbeda nyata dengan umur bibit $21 \mathrm{HSS}$, namun berbeda tidak nyata pada umur bibit 14 dan 35 HSS.

\subsection{Jumlah Anakan Maksimum}

Hasil analisis keragaman pengaruh jumlah bibit dan umur bibit terhadap jumlah anakan maksimun tanaman padi dapat dilihat pada Tabel 4 berikut ini.

Tabel 4. Analisis KeragamanPerlakuan Jumlah Bibit dan Umur Bibit Terhadap Jumlah Anakan Maksimum.

\begin{tabular}{llllll}
\hline $\begin{array}{l}\text { Sumber } \\
\text { Keragaman }\end{array}$ & $\begin{array}{l}\text { Derajat } \\
\text { Bebas }\end{array}$ & $\begin{array}{l}\text { Jumlah } \\
\text { Kuadrat }\end{array}$ & $\begin{array}{l}\text { Kuadrat } \\
\text { Tengah }\end{array}$ & F Hitung & F Tabel 5\% \\
\hline Jumlah Bibit & 4 & 4439,07 & 1169,77 & $109,66^{*}$ & 2,62 \\
Umur Bibit & 3 & 4,3166 & 1,44 & $0,142^{\text {tn }}$ & 2,85 \\
Interaksi & 12 & 81,60 & 6,80 & $0,67^{\text {th }}$ & 2,02 \\
Galat & 38 & 384,57 & 10,12 & & \\
\hline Total & 59 & 4962,98 & & & \\
\hline
\end{tabular}

$\operatorname{KK}(\%)=9,78$

Keterangan: ${ }^{*}$ berpengaruh nyata, $t$ = berpengaruh tidak nyata. 
Berdasarkan hasil analisis keragaman pada Tabel 4 diatas, perlakuan jumlah bibit menunjukkan pengaruh yang nyata terhadap jumlah anakan maksimum, sedangkan perlakuan umur bibit dan interaksinya menunjukkan pengaruh tidak nyata. Selanjutnya untuk mengetahui pengaruh jumlah dan umur bibit terhadap jumlah anakan maksimum dilakukan uji BNJ seperti pada Tabel 5 berikut ini.

Tabel 5. Uji BNJ Perlakuan Jumlah Bibit Terhadap Jumlah Anakan Maksimum.

\begin{tabular}{ll}
\hline Jumlah bibit & Jumlah Anakan Maksimum (anakan) \\
\hline 5 & $20,67 \mathrm{c}$ \\
10 & $25,08 \mathrm{c}$ \\
15 & $33,17 \mathrm{~b}$ \\
20 & $41,50 \mathrm{a}$ \\
25 & $42,17 \mathrm{a}$ \\
\hline BNJ 5\% & 7,43 \\
\hline
\end{tabular}

Keterangan: Nilai yang diikuti dengan huruf yang berbeda menunjukkan perlakuan berbeda nyata pada taraf uji BNJ $5 \%$

Berdasarkan Tabel 5 bahwajumlah anakan maksimum pada perlakuan jumlah bibit 25 pertitik tanam berbeda nyata dengan perlakuan jumlah bibit 5, 10, dan 15 pertitik tanam, namun berbeda tidak nyata dengan perlakuan jumlah bibit 20 pertitik tanam. Kecenderungan rerata jumlah anakan maksimum tertinggi pada perlakuan jumlah bibit 25 pertitik tanam sebesar42,17 anakan maksimum dan kecenderungan hasil terendah pada jumlah bibit 5 pertitik tanam dengan anakan maksimum 20,67.

\subsection{Jumlah Anakan Produktif}

Hasil analisis keragaman pengaruh jumlah bibit dan umur bibit terhadap jumlah anakan produktif dapat dilihat pada Tabel 6berikut ini.

Tabel 6. Analisis Keragaman Jumlah Bibit dan Umur Bibit Terhadap Anakan.

\begin{tabular}{llllll}
\hline $\begin{array}{l}\text { Sumber } \\
\text { Keragaman }\end{array}$ & $\begin{array}{l}\text { Derajat } \\
\text { Bebas }\end{array}$ & $\begin{array}{l}\text { Jumlah } \\
\text { Kuadrat }\end{array}$ & $\begin{array}{l}\text { Kuadrat } \\
\text { Tengah }\end{array}$ & F Hitung & F Tabel 5\% \\
\hline Jumlah Bibit & 4 & 2497,77 & 624,44 & $72,97^{*}$ & 2,62 \\
Umur Bibit & 3 & 34,45 & 11,48 & $1,34^{\text {tn }}$ & 2,85 \\
Interaksi & 12 & 46,63 & 3,89 & $0,45^{\text {tn }}$ & 2,02 \\
Galat & 38 & 325,2 & 8,56 & & \\
\hline Total & 59 & 2930,18 & & & \\
\hline KK $(\%)=11,42$ & & & & & \\
\hline
\end{tabular}

Keterangan: ${ }^{*}=$ berpengaruh nyata, $t n=$ berpengaruh tidak nyata

Berdasarkan hasil analisis keragaman pada Tabel 6, perlakuan jumlah bibit menunjukkan pengaruh nyata terhadap jumlah anakan produktif, sedangkan perlakuan umur bibit dan interaksinya menunjukkan pengaruh yang tidak nyata. Selanjutnya untuk mengetahui pengaruh jumlah dan umur bibit terhadap jumlah perbedaan antar perlakuan jumlah bibit dilakukan Uji BNJ pada Tabel 7 berikut ini. 
Tabel 7. Uji BNJ Perlakuan Jumlah Bibit Terhadap Jumlah Anakan Produktif

\begin{tabular}{ll}
\hline Jumlah bibit & Jumlah Anakan Produktif (anakan) \\
\hline 5 & $17,08 \mathrm{~d}$ \\
10 & $20,12 \mathrm{~cd}$ \\
15 & $25,42 \mathrm{bc}$ \\
20 & $32,17 \mathrm{ab}$ \\
25 & $33,42 \mathrm{a}$ \\
\hline BNJ 5\% & 6,84 \\
\hline
\end{tabular}

Keterangan : Nilai yang diikuti dengan huruf yang berbeda menunjukkan perlakuan berbeda nyata pada taraf uji BNJ 5\%

Hasil uji BNJ pada Tabel 7 menunjukkan bahwa perlakuan jumlah bibit 5 pertitik tanam berbeda tidak nyata dengan perlakuan jumlah bibit 10 dan 15 pertititik tanam,namun berbeda nyata dengan jumlah bibit 20 dan 25 pertitik tanam. Hasil tertinggi terhadap jumlah anakan produktif cenderung pada perlakuan jumlah bibit 25 pertitik tanam yaitu 33,42 anakan.

\subsection{Berat Gabah Kering Panen (g)}

Hasil analisis keragaman pengaruh jumlah bibit dan umur bibit terhadap berat gabah kering panentanaman padi dapat dilihat pada Tabel 8 berikut ini.

Tabel 8. Analisis Keragaman Perlakuan Jumlah Bibit Dan Umur Bibit Terhadap Berat Gabah Kering Panen.

\begin{tabular}{llllll}
\hline $\begin{array}{l}\text { Sumber } \\
\text { Keragaman }\end{array}$ & $\begin{array}{l}\text { Derajat } \\
\text { Bebas }\end{array}$ & $\begin{array}{l}\text { Jumlah } \\
\text { Kuadrat }\end{array}$ & $\begin{array}{l}\text { Kuadrat } \\
\text { Tengah }\end{array}$ & F Hitung & F Tabel 5\% \\
\hline Jumlah Bibit & 4 & 0.0185 & 0.0046 & $3,09^{*}$ & 2.62 \\
Umur Bibit & 3 & 0.0079 & 0.0026 & $1.77^{\text {tn }}$ & 2.85 \\
Interaksi & 12 & 0.0330 & 0.0028 & $1.84^{\text {tn }}$ & 2.02 \\
Galat & 38 & 0.0600 & 0.0015 & & \\
\hline Total & 59 & 0.18 & & & \\
\hline KK $(\%)=17,52$ & & & & & \\
\hline
\end{tabular}

Keterangan: ${ }^{*}=$ berpengaruh nyata, $t n=$ berpengaruh tidak nyata

Berdasarkan hasil analisis keragaman pada Tabel 8, perlakuan jumlah bibit menunjukkan pengaruh nyata terhadap berat gabah kering panen sedangkan perlakuan umur bibit dan interaksinya menunjukkan pengaruh yang tidak nyata. Selanjutnya untuk mengetahui pengaruh jumlah dan umur bibit terhadap berat gabah kering panen dilakukan uji BNJ pada Tabel 9 berikut ini.

Tabel 9. Uji BNJ Perlakuan Jumlah Bibit Terhadap Berat Gabah Kering Panen.

\begin{tabular}{ll}
\hline Jumlah bibit & Berat gabah kering panen $(\mathrm{g})$ \\
\hline 5 & $0.23 \mathrm{ab}$ \\
10 & $0.19 \mathrm{~b}$ \\
15 & $0.24 \mathrm{a}$ \\
20 & $0.22 \mathrm{ab}$ \\
25 & $0.22 \mathrm{ab}$ \\
\hline BNJ 5\% & 0,04 \\
\hline
\end{tabular}

Keterangan : Nilai yang diikuti dengan huruf yang berbeda menunjukkan perlakuan berbeda nyata pada taraf uji BNJ 5\% 
Hasil uji BNJ 5\% pada Tabel 9 menunjukkan bahwa berat gabah kering panen pada perlakuan jumlah bibit 5 pertitik tanam berbeda nyata dibandingkan perlakuan jumlah bibit 10 dan 15 pertitik tanam, akan tetapi berbeda tidak nyata dengan perlakuan jumlah bibit 20 dan 25 pertitik tanam, sedangkan pada perlakuan jumlah bibit 10 dan 15 pertitik tanam berbeda nyata dengan semua perlakuan. Pada perlakuan jumlah bibit 20 dan 25 pertitik tanam menunjukkan hasil berbeda tidak nyata dengan perlakuan jumlah bibit 5 pertitik tanam, akan tetapi berbeda nyata dengan perlakuan jumlah bibit 10 dan 15 pertitik tanam. Pada perlakuan jumlah bibit 15 pertitik tanam cenderung dapat meningkatkan hasil berat gabah kering panen yaitu sebesar $0,24 \mathrm{~g}$.

\subsection{Berat 1.000 Butir (g)}

Hasil analisis keragaman pengaruh jumlah bibit dan umur bibit terhadap berat gabah kering panentanaman padi dapat dilihat pada Tabel 10 berikut ini.

Tabel 10. Analisis Keragaman Perlakuan Jumlah dan Umur Bibit Terhadap Berat 1.000 Butir.

\begin{tabular}{llllll}
\hline $\begin{array}{l}\text { Sumber } \\
\text { Keragaman }\end{array}$ & $\begin{array}{l}\text { Derajat } \\
\text { Bebas }\end{array}$ & $\begin{array}{l}\text { Jumlah } \\
\text { Kuadrat }\end{array}$ & $\begin{array}{l}\text { Kuadrat } \\
\text { Tengah }\end{array}$ & F Hitung & F Tabel 5\% \\
\hline Jumlah Bibit & 4 & 13,38 & 3,34 & $1,53^{\text {tn }}$ & 2,62 \\
Umur Bibit & 3 & 2,91 & 0,97 & $0,44^{\text {th }}$ & 2,85 \\
Interaksi & 12 & 27,79 & 2,32 & $1,059^{\text {tn }}$ & 2,02 \\
Galat & 38 & 83,12 & 2,19 & & \\
\hline Total & 59 & 389,53 & & & \\
\hline KK $(\%)=6,30$ & & & & & \\
\hline
\end{tabular}

Keterangan:tn= berpengaruh tidak nyata

Berdasarkan hasil analisis keragaman pada Tabel 10, perlakuan jumlah dan umur bibit serta interaksinya menunjukkan pengaruh yang tidak nyata terhadap variabel berat 1.000 butir.

\subsection{Berat Gabah Kering Giling Per Tanaman (g)}

Hasil analisis keragaman pengaruh jumlah bibit dan umur bibit terhadap berat gabah kering giling pertanaman pada tanaman padidapat dilihat pada Tabel 11 berikut ini.

Tabel 11. Rerata Perlakuan Jumlah Bibit Terhadap Berat Gabah Kering Giling Pertanaman.

\begin{tabular}{llllll}
\hline $\begin{array}{l}\text { Sumber } \\
\text { Keragaman }\end{array}$ & $\begin{array}{l}\text { Derajat. } \\
\text { Bebas }\end{array}$ & $\begin{array}{l}\text { Jumlah } \\
\text { Kuadrat }\end{array}$ & $\begin{array}{l}\text { Kuadrat } \\
\text { Tengah }\end{array}$ & F Hitung & F Tabel 5\% \\
\hline Jumlah Bibit & 4 & 158,05 & 39,51 & $2,53^{\text {tn }}$ & 2,62 \\
Umur Bibit & 3 & 163,45 & 54,48 & $3,49^{*}$ & 2,85 \\
& & & & & \\
Interaksi & 12 & 105,46 & 8,79 & $0,56^{\text {th }}$ & 2,02 \\
& & & & & \\
Galat & 38 & 592,57 & 15,59 & & \\
\hline Total & 59 & 1515,91 & & & \\
\hline KK $(\%)=23$ & & & &
\end{tabular}

Keterangan ${ }^{*}=$ berpengaruh nyata, $t n=$ berpengaruh tidak nyata

Berdasarkan hasil analisis keragaman pada Tabel 11 diatas, perlakuan umur bibit menunjukkan pengaruh yang nyata terhadap berat gabah kering giling pertanaman, sedangkan perlakuan jumlah bibit dan interaksinya menunjukkan pengaruh yang 
tidak nyata. Selanjutnya untuk mengetahui pengaruh umur dan jumlah bibit terhadap berat gabah kering giling per tanaman dilakukan BNJ pada Tabel 12 berikut ini.

Tabel 12. Uji BNJ Perlakuan Umur Bibit Terhadap Berat Gabah Kering Giling Pertanaman.

\begin{tabular}{ll}
\hline Umur Bibit (HSS) & Rerata \\
\hline 14 & $14,80 \mathrm{~b}$ \\
21 & $16,61 \mathrm{ab}$ \\
28 & $17,86 \mathrm{ab}$ \\
35 & $19,16 \mathrm{a}$ \\
\hline BNJ 5\% & 4,30 \\
\hline
\end{tabular}

Keterangan : Nilai yang diikuti dengan huruf yang berbeda menunjukkan perlakuan berbeda nyata pada taraf uji BNJ 5\%

Hasil analisis dari perlakuan umur bibit terhadap berat gabah kering giling pertanaman menunjukkan adanya pengaruh nyata. Perlakuan umur bibit 14 HSS berbeda tidak nyata terhadap perlakuan umur bibit 21 dan 28 HSS tetapi berbeda nyata dengan perlakuan umur bibit 35 HSS. Pada perlakuan dengan umur bibit 21 HSS berbeda tidak nyata terhadap perlakuan umur bibit 14,28 dan 35. Secara statistik pemberian perlakuan dengan umur bibit 14 HSS menunjukkan tidak terjadi peningkatan hasil dengan perlakuan umur bibit 21 dan 28 HSS dengan hasil 16,61 g, dan 17,68 g, tetapi ketika diberi perlakuan dengan umur bibit 35 HSS terjadi peningkatan hasil berat gabah kering giling pertanaman yaitu $19,16 \mathrm{~g}$.

\subsection{Berat Gabah Kering Giling per Petak (g)}

Hasil analisis keragaman pengaruh jumlah bibit dan umur bibit terhadap berat gabah kering giling per petak tanaman padi pada lahan tadah hujan dapat dilihat pada Tabel 13 berikut ini.

Tabel 13. Analisis Keragaman Perlakuan Jumlah Bibit Dan Umur Bibit Terhadap Berat Gabah Kering Giling per Petak $(\mathrm{g})$

\begin{tabular}{llllll}
\hline $\begin{array}{l}\text { Sumber } \\
\text { Keragaman }\end{array}$ & $\begin{array}{l}\text { Derajat } \\
\text { Bebas }\end{array}$ & $\begin{array}{l}\text { Jumlah } \\
\text { Kuadrat }\end{array}$ & $\begin{array}{l}\text { Kuadrat } \\
\text { Tengah }\end{array}$ & F Hitung & F Tabel 5\% \\
\hline umlah Bibit & 4 & 217640 & 54410 & $0,73^{\text {tn }}$ & 2,62 \\
Umur Bibit & 3 & 604500 & 201500 & $2,71^{\text {tn }}$ & 2,85 \\
Interaksi & 12 & 257466,66 & 21455,55 & $0,29^{\text {tn }}$ & 2,02 \\
Galat & 38 & 2830213,33 & 74479,29 & & \\
\hline Total & 59 & 7514073,33 & & & \\
\hline KK $(\%)=16.5$ & & & & & \\
\hline
\end{tabular}

Keterangan:tn= berpengaruh tidak nyata

Berdasarkan hasil analisis keragaman pada Tabel 13 diatas, perlakuan jumlah dan umur bibit serta interaksinya menunjukkan pengaruh yang tidak nyataterhadap berat gabah kering giling perpetak.

Berdasarkan hasil penelitian diperoleh bahwa interaksi antara jumlah bibit dan umur bibit berpengaruh tidak nyata terhadap semua variabel pengamatan. Perlakuan jumlah bibit berpengaruh nyata terhadap variabel tinggi tanaman umur 2, 4, 5 MST, jumlah anakan maksimum, jumlah anakan produktif dan berat gabah kering panen, sedangkan perlakuan umur bibit berpengaruh nyata terhadap variabel tinggi tanaman umur 2, 3, 4, 5 MST dan gabah kering giling per tanaman.

Penanaman bibit dengan jumlah yang relatif lebih banyak mendorong pertumbuhan tinggi tanaman lebih tinggi bila dibandingkan dengan penanaman bibit tanamanyang lebih sedikit pada satu lubang tanam. Hal ini disebabkan karena pada jumlah bibit yang lebih banyak dapat mengakibatkan kompetisi 
inter spesies diantara rumpun tanaman padi per lubang tanam, sedangkan yang ditanam lebih sedikit tidak terjadi kompetisi tersebut, sehingga lebih mendorong pertumbuhan kearah samping atau memperbanyak jumlah anakan.Menurut Harjadi (1984) bahwa cahaya dan air adalah merupakan faktor penting di dalam peristiwa fotosintesis, apabila unsur-unsur ini berada dalam keadaan optimum maka jumlah fotosintat yang dihasilkan oleh suatu tanaman akan lebih banyak, sehingga dapat memberikan kontribusi yang lebih besar terhadap pertumbuhan dan hasil tanaman. Perlakuan jumlah bibit tanam juga memberikan pengaruh nyata terhadap jumlah anakan maksimum, anakan produktif dan berat gabah kering panen.

Pengaruh umur bibit berpengaruh nyata terhadap tinggi tanaman padi pada umur 2,3, 4 dan 5 MST, sedangkan pada umur 1 MST berpengaruh tidak nyata. Pemindahan bibit ke lapangan harus disesuaikan dengan tingkat perkembangan akar, sehingga pada waktu pemindahan bibit tidak terjadi kerusakan akar. Apabila akar mengalami kerusakan maka untuk pertumbuhan awal bibit memerlukan waktu penyembuhan padahal anakan maksimum terjadi sampai pada batas umur 49-50 HSS serta perkembangan akar umumnya akan terhenti pada umur 42 HSS (Thangaraj and O'Toole 1985).

Kondisi umur bibit yang masih terlalu muda memiliki perakaran yang belum terlalu kuat, perakaran dan batang padi yang masih muda mengakibatkan akar tanaman padi lambat untuk mendapatkan air, unsur hara, $\mathrm{CO}^{2}, \mathrm{O}^{2}$, cahaya, sehingga pertumbuhan akan menjadi tidak normal. Menurut Abdullah (2004) bahwa perlakuan umur bibit sampai 3 minggu setelah semai tidak terlihat pengaruhnya terhadap tinggi tanaman. Tabel 7 menunjukkan bahwa perlakuan jumlah bibit tanaman mempengaruhi jumlah anakan produktif sedangkan pada perlakuan umur bibit terhadap anakan produktif memberikan hasil yang berbeda tidak nyata. Jumlah bibit yang lebih sedikit menunjukkan hasil yang berbeda nyata terhadap perlakuan jumlah bibit 15, 20 dan 25 pertitik tanam. Selanjutnya Husana (2010) menjelaskan bahwa jumlah anakan akan maksimal apabila tanaman memiliki sifat genetik yang baik di tambah dengan keadaan lingkungan yang menguntungkan atau sesuai dengan pertumbuhan dan perkembangan tanaman.

Pengamatan penelitian terhadap jumlah anakan maksimum menunjukkan bahwa perlakuan jumlah bibit berpengaruh nyata terhadap jumlah anakan maksimum. Semakin banyak jumlah bibit per titik tanam semakin sedikit jumlah anakan dan anakan produktif. Rumpun yang berasal dari perlakuan yang lebih banyak memperlihatkan jumlah anakan dan anakan produktif yang lebih sedikit. Persaingan sejak awal antar lembaran daun secara langsung diduga telah menurunkan kebugaran (vigor) anakan. Bertambahnya jumlah bibit per tanaman cenderung meningkatkan persaingan baik antara tanaman dalam satu rumpun maupun dengan rumpun lainnya terhadap cahaya, ruang dan unsur hara sehingga mempengaruhi pertumbuhan dan hasil tanaman.

Banyaknya jumlah anakan sangat mempengaruhi potensi hasil gabah. Semakin banyak anakan produktif maka semakin tinggi potensi hasil gabah. Selain jumlah anakan produktif yang berpengaruh terhadap hasil gabah, umur bibit tanaman juga memegang peranan penting dalam meningkatkan hasil gabah.

Selanjutnya perlakuan jumlah dan umur bibit berpengaruh tidak nyata terhadap berat 1.000 butir dan berat gabah kering giling per petak. Hal tersebut diduga dengan bertambahnya jumlah bibit per tanaman cenderung meningkatkan persaingan baik antara tanaman dalam satu rumpun maupun dengan rumpun lainnya terhadap cahaya, ruang dan unsur hara sehingga mempengaruhi pertumbuhan dan produksi. Lakitan (2008) menyatakan bahwa jumlah unsur hara yang dibutuhkan tanaman tersebut sangat berkaitan dengan kebutuhan tanaman untuk dapat tumbuh dengan lebih baik, jika jumlah unsur hara kurang tersedia maka pertumbuhan akan terhambat, tetapi apabila jumlah unsur hara yang tersedia lebih tinggi dari pada angka kebutuhan unsur hara oleh tanaman maka dapat dikatakan sebagai kondisi konsumsi mewah.

Selanjutnya pengamatan terhadap
variabel berat gabah kering panen


menunjukkan bahwa perlakuan jumlah bibit berpengaruh nyata, namun umur bibit berpengaruh tidak nyata. Pada perlakuan jumlah bibit 5 per titik tanam menghasilkan berat gabah kering panen tertinggi dibandingkan jumlah bibit yang lebih banyak. Bertambahnya jumlah bibit yang lebih banyak akan meningkatkan persaingan baik antar tanaman dalam satu rumpun maupun dengan yang lainnya terhadap sumber daya yang dibutuhkan tanaman, seperti: unsur hara, sinar matahari, dan ruang tumbuh. Hal tersebut tentunya akan mengurangi hasil fotosintesis bersih yang berdampak terhadap penurunan berat gabah kering panen.

Jumlah bibit yang terbaik dalam memberikan hasil gabah dipengaruhi oleh lingkungan dan varietas yang ditanam. Hal ini sesuai dengan pernyataan Setyati (2002) bahwa penentuan jumlah tanaman per lubang tanam erat sekali hubungannya dengan tingkat populasi tanaman. Kepadatan populasi tanaman akan mempengaruhi pertumbuhan dan produksi tanaman. Selain itu, penggunaan sarana tumbuh yang optimal mendorong terpacunya pertumbuhan yang lebih baik.

Hasil pengamatan terhadap berat gabah kering giling per tanaman menunjukkan bahwa perlakuan umur bibit menunjukkan pengaruh nyata, namun jumlah bibit berpengaruh tidak nyata. Perlakuan umur bibit 21 per titik tanam menghasilkan berat gabah kering giling per tanaman tertinggi. Pada perlakuan umur bibit yang lebih muda menghasilkan berat gabah kering giling yang lebih rendah, namun pada perlakuan umur bibit yang lebih tua juga menghasilkan berat gabah kering giling yang semakin rendah. Hal ini menunjukkan bahwa pada perlakuan umur bibit yang lebih tua akan berakibat pada penurunan hasil. Pemindahan bibit pada umur muda masih dalam kondisi akar yang muda sehingga ketika akan memindahkan bibit ke lapangan harus disesuaikan dengan tingkat perkembangan akar, sehingga pada waktu pemindahan bibit tidak terjadi kerusakan akar, apabila akar mengalami kerusakan maka untuk pertumbuhan awal bibit memerlukan waktu penyembuhan dan akhirnya berpengaruh pada pertumbuhan selanjutnya termasuk hasil produksi gabah.
Selanjutnya pada umur yang lebih tua menyebabkan kemampuan tumbuh tanaman semakin berkurang. Umur bibit yang lebih tua cenderung untuk fase pertumbuhan generatif sehingga berpengaruh terhadap peningkatan hasil gabah.Kurniasih (2008) melaporkaan bahwa penggunaan umur bibit yang lebih muda pada saat tanam dapat mempercepat umur berbunga dan umur panen, tetapi tidak berpengaruh terhadap perakaran atau hasil gabah per rumpun maupun per hektar.Penanaman bibit muda dari persemaian efektif menekan ruas batang tanaman dibandingkan dengan penggunaan umur bibit tua (Kim, 1999).

Kondisi lingkungan seperti ketersediaan air, suhu dan kelembaban udara serta hama dan penyakit sangat mempengaruhi pertumbuhan tanaman padi. Tanaman padi dapat hidup baik di daerah yang berhawa panas dan banyak mengandung uap air. Curah hujan yang baik rata-rata 200 $\mathrm{mm}$ per bulan atau lebih, dengan distribusi selama 4 bulan, curah hujan yang dikehendaki per tahun sekitar 1.500-2.000 $\mathrm{mm}$. Suhu yang baik untuk pertumbuhan tanaman padi $23{ }^{\circ} \mathrm{C}$. Selama penelitian ketersediaan air untuk tanaman padi masih terpenuhi. Hama yang dihadapi pada saat penelitian yang utama adalah berupa serangan hama walang sangit yang terjadinya diakhir penelitian, atau ketika tanaman memasuki umur panen sehingga menganggu tanaman padi. Serangan hama tikus tidak ditemukan dikarenakan areal pertanaman rutin dibersihkan dari gulma yang tumbuh

\section{KESIMPULAN}

Berdasarkan hasil penelitian yang telah dilakukan dapat ditarik kesimpulan sebagai berikut: Tidak terdapat interaksi antara perlakuan jumlah bibit dan umur bibit terhadap pertumbuhan dan hasil padi pada laha sawah tadah hujan.

Perlakuan jumlah bibit 5 per titik tanam merupakan perlakuan terbaik yang dapat meningkatkan pertumbuhan dan hasil tanaman padi pada lahan sawah tadah hujan. 
Perlakuan umur bibit 21 hari setelah semai merupakan perlakuan yang terbaik dalam meningkatkan hasil tanam padi pada lahan sawah tadah hujan.

\section{DAFTAR PUSTAKA}

Abdullah, S. (2004). Pengaruh perbedaan jumlah dan umur bibit terhadap pertumbuhan dan hasil padi sawah. Prosiding Seminar Nasional Penerapan Agroinovasi Mendukung Ketahanan Pangan dan Agribisnis. Sukarami, 10-11 Agustus 2004; 154-161 hlm.

Badan Pusat Statistik Provinsi Kalimantan Barat. (2014). Statistik Pertanian Tanaman Pangan Provinsi Kalimantan Barat Tahun 2014. Pontianak.

Harjadi, S..M.M. (1984). Pengantar Agronomi. Jakarta: Gramedia.

Husana, Y. (2010). Pengaruh Penggunaan Jarak Tanam Terhadap Pertumbuhan dan Produksi Padi Sawah (Oryzasativa L.) Varietas IR 42 dengan Metode SRI (System of Rice Intensification). Jurnal Jurusan Agroteknologi. Fakultas Pertanian. Universitas Riau.
Kim, S. S., B. K. Kim, M. G. Choi, M. H. Back, W. Y. Choi, and S. Y. Lee. (1999). Effect Of Seedling Age On Gowth And Yield Of Machine Transplanted Rice In Southrern Plain Region. Korean J. of Sci.

Kurniasih, B. A., S. Fatimah, D.A. Purnawati. (2008). Karakteristik Perakaran Tanaman Padi Sawah IR64 (OryzaSativa L.) Pada Umur Bibit Dan Jarak Tanam Yang Berbeda. Jurnal Ilmu Pertanian

Lakitan, B. (2008). Dasar-Dasar Fisiologi Tumbuhan. Jakarta: Raja Grafindo Persada.

Setyati, S. (2002). Pengantar Dasar Agronomi. Jakarta: Gramedia.

Tangaraj, M., dan J.C. O'Toole. (1985). Root Behavior, Field and Laboratory Studies for Rice and non Rice Crops. In Soil Physics and Rice, International Rice Research Institute, Los Banos, Laguna, Philippines. 